\title{
ESTIMATE AND PREDICTIVE MODEL OF REGIONAL GEODEMOGRAPHIC SYSTEM
}

\author{
Kateryna SEHIDA \\ V.N. Karazin Kharkiv National University, Ukraine \\ kateryna.sehida@gmail.com
}

\begin{abstract}
The regional geodemographic system is a typical subject of a human geographer. Estimate and predictive model of geodemographic system, proposed in this paper, is created for pilot study of development tendencies of geodemographic system and forecasting of its changes in view of various management scenarios. Creation of a model needs for several preparatory stages. The first stage is an idealization of the studied system. The next one is formalization that provides transition from the figurative and verbal description of a model to unambiguous representations by means of formal logic in the form of balance equations. To describe the changes of geodemographic system, a balance equation is used, describing each settlement or each local geodemographic system as a part of regional geodemographic system. The final stage implies parametrization and input of entry conditions. Flexibility of the model algorithm allows realizing four main options, listed here from the least to the most complicate: a) retrospective analysis for identification of the main temporary tendencies of regional geodemographic system functioning; b) short-time or long-time forecasting of a regional geodemographic system according to various options of its development; c) use of the model to manage the development of regional geodemographic situation; d) creation of online permanent model of regional geodemographic system and its development. The letter option represents a perspective and utmost practical application of the proposed estimate and predictive model in public management.
\end{abstract}

Key words: population, geodemographic system, geodemographic processes, modeling, estimate and predictive model.

DOI: https://doi.org/10.17721/2413-7154/2017.77.85-91

UDC: 911.3

\section{ОЦІНОЧНО-ПРОГНОСТИЧНА МОДЕЛЬ ГЕОДЕМОГРАФІЧНОЇ СИСТЕМИ РЕГІОНУ}

\author{
Катерина СЕГІДА \\ Харківський національний університет імені В. Н. Каразіна, Україна \\ kateryna.sehida@gmail.com
}

\begin{abstract}
Анотація: Геодемографічна система регіону $\epsilon$ типовим об'єктом суспільно-географічних досліджень. Оціночно-прогностична модель геодемографічної системи створена для експериментального дослідження тенденцій розвитку геодемографічної системи і прогнозування її змін за різними сценаріями управління. Побудова моделі вимагає виконання кількох підготовчих стадій. Перша з них - це ідеалізація досліджуваної системи. Наступна стадія моделювання - стадія формалізації - передбачає перехід від образного і вербального опису моделі до однозначного представлення її засобами формальної логіки у вигляді математичних рівнянь балансового типу. Для опису зміни стану геодемографічної системи використовується балансове рівняння, яке описує кожне поселення або локальну геодемографічну систему у складі регіональної геодемографічної системи. Наступна стадія побудови моделі - параметризація і задання початкових умов. Гнучкість алгоритму функціонування моделі дозволяє реалізувати чотири основні варіанти її використання (у порядку ускладнення): а) ретроспективний аналіз для виявлення основних часових тенденцій функціонування регіональної геодемографічної системи; б) прогнозування стану регіональної геодемографічної системи на ближню та середню перспективу за різними варіантами їі розвитку; в) використання моделі у процесі управління формуванням і розвитком регіональної геодемографічної ситуації; г) створення постійно діючої в оn-Ііne режимі моделі регіональної геодемографічної системи та її розвитку. Створення постійно діючої моделі регіональної геодемографічної системи $\epsilon$ перспективною граничною реалізацією ідеї застосування запропонованої оціночно-прогностичної моделі в суспільному управлінні.
\end{abstract}

Ключові слова: населення, геодемографічна система, геодемографічні процеси, моделювання, оціночнопрогностична модель.

DOI: https://doi.org/10.17721/2413-7154/2017.77.85-91

УДК: 911.3

Вступ. Для узгодженого розвитку держави необхідною складовою є трансформація цілей та задач європейської i національної стратегій на регіональний рівень із адаптацією до конкретної ситуації, адже саме тепер необхідним є узгоджене

виконання зазначених програм. Стратегія розвитку Харківської області до 2020 року [9], Концепція розвитку міста Харкова до 2030 року визначають одним із ключових завдання збагачення демографічного капіталу регіону, тож значимість цього феномену не викликає сумніві ані в науковців, 
ані в управлінців. Враховуючи, що Харківщина $є$ однією 3 найбільш чисельних областей України та залишається потужним науковим, економічним, культурним центром. В той же час, система розселення Харківського регіону $є$ моноцентричною, що обумовлює гіпертрофований розрив в показниках соціально-економічного розвитку між обласним центром та іншими територіями області. Надмірна концентрація населення в Харкові та ряд характерних демографічних проблем (відтік населення та його старіння в більшості периферійних районах області) створюють значні диспропорції в рівні та якості життя населення, які з року в рік загострюються та гальмують загальний розвиток області [3, 5]. Зазначене зумовлює необхідність та своєчасних суспільно-географічних досліджень населення регіону. Сучасні географічні дослідження все частіше спрямовані на практичне розв' язання актуальних проблем розвитку територій різного рівня, що особливо стосується суспільногеографічних досліджень. Тож, одночасно із стрімким розвитком науки, інтеграцією окремих ii галузей 3 одного боку та виділенням нових - 3 іншого, активно розвивається методологія суспільної географії. Новий суспільний запит формує необхідність комплексних суспільногеографічних досліджень, спрямованих, зокрема, на вирішення актуальних проблем регіонального розвитку. До таких досліджень відносяться регіональні геодемографічні дослідження.

Теоретико-методологічні

дослідження. Грунтуючись на суспільногеографічному підході, геодемографічну систему слід розглядати як функціональну складову соціогеосистеми, яку становить населення території з усім комплексом демографічних і територіальних структур, поведінкових i інших особливостей. Геодемографічна система $\epsilon$ основою соціуму i суспільства, $є$ динамічною та сенсибілізованою до впливу зовнішніх i внутрішніх факторів, $\epsilon$ такою системою, що самоорганізується та саморозвивається; є системою, в якій відбуваються геодемографічні процеси, забезпечуючи безперервне відтворення населення, змінюючи кількісні і якісні характеристики в просторовочасовому континуумі [7]. Геодемографічна система регіону є типовим об'єктом суспільногеографічних досліджень, тому за мету в статті поставлено обгрунтування оціночно-прогностичної моделі регіональної геодемографічної системи 3 позиції суспільної географії. Реалізація зазначеної мети зводиться до виконання наступних завдань: встановлення основних складових, які описують розвиток геодемографічної системи регіону, опис стадій моделювання, розкриття варіантів застосування запропонованої моделі, аналіз можливостей використання оціночнопрогностичної моделі геодемографічної системи у процесі управління.

Опис методики дослідження та здобутих емпіричних даних. Оціночно-прогностична модель геодемографічної системи створена для експериментального дослідження тенденцій розвитку геодемографічної системи i прогнозування іiі змін за різними сценаріями управління. Як вже зазначалось, геодемографічна система $\epsilon$ складною динамічною відкритою системою, яка забезпечує відтворення населення регіону. Безпосередніми процесами формування наявного населення $\epsilon$ природний та механічний рух населення. Природний рух населення сприяє безперервному оновленню поколінь, неперервному потоку населення, баланс якого має дві складові. Перша 3 них - приходна - розуміється як народжуваність, тобто, поява нових індивідів дитячого віку як поповнення населення. Друга - розхідна - розглядається як смертність, тобто, відхід 3 життя за різними причинами певної частки людей переважно середнього або похилого віку. Відтворення населення шляхом природного руху зумовлене балансом цих двох складових.

Для розвинених країн оптимальним, як показує досвід, є сталий паритетний, або слабо зміщений у бік смертності природний рух населення. Цьому сприяє досконала, ефективно працююча соціальна інфраструктура та високий рівень життя людей, що $є$ вирішальними умовами для простого відтворення населення. Для країн, які відносно недавно звільнилися від колоніального гніту, зберігається певний час (кілька десятиліть) тенденція до високої народжуваності, пов'язана 3 несприятливими умовами життя і високим рівнем дитячої смертності. Після отримання незалежності вони реформували суспільство і умови виживання суттєво поліпшилися, що спричинило ефект демографічного вибуху, тобто, розширеного відтворення населення. Є й такі країни, які мають відносно високий рівень розвитку, але вимушені відстоювати свою незалежність у суверенітет ціною тимчасового зниження ефективності суспільного виробництва та управління, часткової втрати виробничого потенціалу i різкого зниження народжуваності й зростання смертності. На жаль, до таких країн відноситься і Україна, яка змушена витрачати свій суспільний ресурс на протистояння окупації і відстоювання незалежності.

Другий аспект відтворення населення механічний рух населення - інтегрально відображає конкурентоздатність територій країн, регіонів, місцевостей, поселень тощо. Для регіональної геодемографічної системи найважливішим $є$ внутрішньорегіональна міграція населення, тобто, його перерозподіл між різними районами та поселеннями. Зовнішня міграція є значно меншою за обсягом. Виключенням є міграція, що стосується певних обставин суспільного життя (наприклад, особи, тимчасово переміщені із окупованих територій тощо). Але у будь-якому випадку такі мігранти розподіляються переважно в містах регіону і на закономірності внутрішньорегіональної міграції суттєво не впливають. Таким чином, відкритість геодемографічної системи у цьому аспекті теж сприяє потоку людей в регіон i $з$ регіону.

Побудова моделі вимагає виконання кількох підготовчих стадій. Перша 3 них - це ідеалізація 
досліджуваної системи. Її головне завдання створення віртуального образу майбутньої моделі у свідомості, тобто, первинний аналіз реальної системи, відбір визначальних іiі ознак (важливих 3 точки зору функціонування моделі) і деякого, інколи суттєвого спрощення ii структури. Виходячи 3 того, що найвиразнішими показниками геодемографічної системи є три основні параметри: численність населення, вікова структура населення та обсяги міграції, в моделюванні вони прийняті у якості контрольних параметрів процесу відтворення населення опорних поселень (міста i районні центри) внаслідок його природного та механічного руху порівняно 3 початковим моментом [1, 2, 6, 8, 10, 11].

Наступна стадія моделювання - стадія формалізації - передбачає перехід від образного i вербального опису моделі до однозначного представлення ㄲï засобами формальної логіки у вигляді математичних рівнянь еволюційного або балансового типу. Моделі на основі еволюційних рівнянь містять часові похідні визначальних показників i частіше всього $є$ системами диференційних рівнянь. Їх побудова потребує застосування певних формалізованих теоретичних знань, концепцій, законів тощо. Крім цього розрахункові схеми на основі диференційних рівнянь дуже вимогливі до методу розрахунків. Побудова моделей на основі балансових рівнянь формально $є$ значно простішою. В таких моделях, як правило, час враховується неявно завдяки використанню принципу зміни стаціонарних станів системи. Названий принцип передбачає поділення всього досліджуваного періоду $\boldsymbol{T}$ на відносно невеликі часові відрізки $\boldsymbol{\Delta t}$, розділені розрахунковими моментами часу $\boldsymbol{t}_{\boldsymbol{p}}$ При цьому стан системи описується балансовими рівняннями саме на ці моменти часу і вважається стаціонарним. Отже, вся траєкторія геодемографічного розвитку представлена точками, кожна 3 яких відповідає певному розрахунковому моменту часу $\boldsymbol{t}_{\boldsymbol{p}}$. Для опису зміни стану геодемографічної системи використовується балансове рівняння, яке описує кожне поселення або локальна геодемографічна система у складі регіональної геодемографічної системи:

$$
N=\sum_{i}^{m} N_{i}=\sum_{i}^{m}\left(N_{M, i}-N_{u, i}-N_{e, i}\right)+N_{r}
$$

де $N$ - наявного населення у даній геодемографічній системі на розрахунковий момент часу; $\boldsymbol{N}_{\boldsymbol{i}}$ - чисельний склад $i$-тої вікової групи; $N_{M, i}$ - число осіб в $i$-тій віковій групі, прибулих протягом періоду $\boldsymbol{\Delta t} ; \boldsymbol{N}_{u, i}-$ число померлих осіб в $i$-тій віковій групі протягом періоду $\Delta t ; N_{e, i}-$ число осіб в $i$-тій віковій групі, вибулих протягом періоду $\boldsymbol{\Delta t}$; $N_{r}-$ число народжених у даній системі протягом періоду $\boldsymbol{\Delta t} ; \boldsymbol{m}$ - кількість вікових груп у даній системі; $\boldsymbol{i}$ - поточний індекс вікової групи.

Складова $\boldsymbol{N}_{r}$ відноситься до першої вікової групи (вік до 1 року). Початковий склад кожної вікової групи на наступний період визначається методом заміщення, тобто, кінцевим складом попередньої вікової групи. Зміни складу протягом періоду $\boldsymbol{\Delta t}$ визначаються за формулою (1).

Наступна стадія побудови моделі параметризація і задання початкових умов. Вона передбачає визначення численних параметрів моделі і початкових умов на момент $\boldsymbol{t}_{\boldsymbol{p}}=0$. Важливим параметром моделі $\epsilon$ тривалість розрахункового періоду $\boldsymbol{\Delta t}$. 3 усіх точок зору оптимальним є значення $\boldsymbol{\Delta t}=1$ рік, яке добре узгоджується 3 інтервалом вікових категорій і прийнятою у державній службі статистики частотою представлення статистичних даних. Як було зазначено вище, контрольними параметрами (змінними) моделі є кількість померлих, прибулих і вибулих осіб у кожній віковій категорії, а також народжених протягом поточного розрахункового періоду. Тому основними початковими значеннями $€$ кількісні склади вікових груп (визначаються за статистичними даними), коефіцієнти смертності за віковими групами (усереднені за певний період) i коефіцієнти народжуваності (визначаються за аналізом часового тренду). Крім цього задаються найбільш ймовірні діапазони міграції у кожній віковій групі. Враховуючи, що міграційні потоки можуть бути зустрічними, фактично на моделі задаються не фізичні обсяги міграції, а значення сальдо міграції.

Балансові рівняння чисельності кожної вікової групи складаються для всіх досліджуваних об'єктів (поселень або геодемографічних систем) i в результаті отримуємо систему балансових рівнянь, яка розв'язується будь-яким методом розрахунку. Слід зазначити, що для моделювання взаємодії об'єктів або геодемографічних систем можна використовувати різні сценарії. Для сценарію моноцентричного розвитку регіону (яка справедлива для Харківської області) модель налаштовується таким чином, що міграція спрямована переважно до обласного центру. Для сценарію поліцентричного розвитку (прогнозного для Харківщини) деякі міста чи районні центри визначаються як об'єкти 3 позитивним сальдо i тоді можна моделювати різні варіанти розвитку регіональної геодемографічної системи. Для врахування ймовірнісного характеру міграційних процесів в алгоритмі реалізації моделі передбачено використання генератора випадкових чисел, за допомогою якого випадковим чином визначається число мігрантів 3 діапазону кожної вікової групи.

Після побудови моделі концепцією дослідження передбачена стадія «навчання» моделі - рішення зворотних задач методом ретроспективного аналізу. При цьому уточнюються всі параметри народжуваності, смертності і міграції, завдяки чому досягається необхідна точність моделі. Слід підкреслити, що результати моделювання мають ймовірнісний характер, що оптимально відповідає випадковому характеру міграції.

\section{Застосування}

оціночно-прогностичної

моделі для вирішення різних задач розглядається як розвиток ідей моделювання траєкторії розвитку соціогеосистем, викладених у низці робіт К. Нємця i Л. Нємець i узагальнених за участю автора у роботі [4], і вимагає додаткового обгрунтування. 
Як зазначалося вище, головною метою створення оціночно-прогностичної моделі $€$ комп'ютерний експеримент для дослідження основних тенденцій розвитку регіональної геодемографічної системи i прогнозування iii стану за різними сценаріями розвитку. Гнучкість алгоритму функціонування моделі дозволяє реалізувати чотири основні варіанти ії використання (у порядку ускладнення):

a) ретроспективний аналіз для виявлення основних часових тенденцій функціонування регіональної геодемографічної системи;

б) прогнозування стану регіональної геодемографічної системи на ближню та середню перспективу за різними варіантами її розвитку;

в) використання моделі у процесі управління формуванням і розвитком регіональної геодемографічної ситуації;

г) створення постійно діючої в on-line режимі моделі регіональної геодемографічної системи та іiі розвитку.

Кожний з перерахованих варіантів використання оціночно-прогностичної моделі геодемографічної системи має особливості, які розглянемо нижче.

Ретроспективний аналіз застосовується у двох випадках:

- 3 метою епігнозного моделювання для уточнення параметрів моделі та іiі адаптації до конкретного процесу;

- для відтворення на моделі недавньої історії 3 метою оцінки впливу окремих факторів, уточнення зв'язків між елементами та підсистемами геодемографічної системи, виявлення основних закономірностей, завуальованих випадковими флуктуаціями факторів тощо (це більш загальний випадок, який за змістом поглинає епігнозне моделювання).

У задачі адаптаиії моделі головним завданням моделювання $є$ уточнення параметрів моделі, початкових i граничних умов, а також часткова перевірка певних гіпотез. Для побудови епігнозної моделі використовується вибірка показників за певний період його історії. У першому наближенні модель будується, виходячи 3 теоретичних або гіпотетичних міркувань. Далі історія процесу відтворюється на моделі крок за кроком. На кожному кроці моделювання перевіряється адекватність моделі реальному процесу, для чого використовуються так звані критерії узгодження співвідношення модельних і реальних параметрів:

$$
\boldsymbol{K} r_{i}=\boldsymbol{P}_{p, i} / \boldsymbol{P}_{m, i}
$$

або

$$
\boldsymbol{K} \boldsymbol{r}_{i}=\frac{\left|\boldsymbol{P}_{p, i}-\boldsymbol{P}_{m, i}\right|}{\boldsymbol{P}_{p, i}}
$$

де $\boldsymbol{K} \boldsymbol{r}_{i}$ - критерій узгодження і-того параметру; $\boldsymbol{P}_{p, i}-$ i-тий параметр реального процесу; $\boldsymbol{P}_{\boldsymbol{m}, \boldsymbol{i}}-\mathrm{i}$-тий параметр моделі.

При перевищенні критерію узгодження встановленого критичного значення відповідні параметри моделі коригуються i розрахунок повторюється до отримання прийнятних значень критеріїв узгодження за всіма параметрами. При цьому досягається динамічний баланс між досягнутими рівнями формалізації i точності моделі.

У деяких випадках, коли вибіркова сукупність параметрів досить велика (більше 20-30 періодів часу), для досягнення більшої об'єктивності моделювання ретроспективна вибірка розділяється на дві частини - «навчальну» і «контрольну», що відповідає перенесенню точки актуального часу на певний період назад. Тоді «навчальна» вибірка використовується для адаптації моделі, як описано вище, а «контрольна» - для оцінки її працездатності і об'єктивної точності за критеріями узгодження (2a, 2б). Інакше кажучи, за «контрольною» вибіркою здійснюється прогнозне моделювання.

Оціночна задача вирішується на адаптованій моделі і є більш складною за змістом і технологією. За допомогою оціночної моделі 3'ясовуються зв'язки між зовнішніми факторами розвитку геодемографічної системи i встановлюється їх вплив на процес відтворення населення. У цьому випадку модель відіграє роль інструменту для відображення реакції геодемографічної системи на зміни зовнішнього середовища, а сама модель добудовується рівняннями зв'язку зовнішніх факторів 3 параметрами геодемографічного процесу. Як правило, у першому наближенні ці рівняння визначаються за результатами лінійного регресійного аналізу. Оціночне моделювання 3 різними граничними умовами, які імітують вплив зовнішнього середовища, дозволяе уточними параметри зв'язків і встановити закономірності функціонування геодемографічної системи в різних умовах. Відповідно до цього розраховуються форма i сила зв'язків параметрів процесу i факторів зовнішнього середовища. Крім цього, при вирішенні оціночних задач уточнюються особливості внутрісистемних зв'язків, що поглиблює знання про внутрішні функції і структуру геодемографічної системи. На відміну від дослідження часового тренду на множині спостережених параметрів, коли рівняння тренду статистично описує зміни цих параметрів у часі, оціночне моделювання дає можливість розкрити та описати механізми ïx динаміки в залежності від стану зовнішнього середовища. Тому оціночна модель дає значно більше корисної інформації про внутрішньосистемні та зовнішні зв'язки геодемографічної системи. Слід додати, що часовий аналіз доцільно доповнити просторовим аналізом (наприклад, ІВФмоделюванням), що, врешті-решт, найбільш повно відтворює історію геодемографічних процесів в соціогеосистемі.

Прогнозне моделювання виконується за допомогою адаптованої моделі і має метою відтворення стану геодемографічної системи на певний момент часу у майбутньому. Як правило, загальна стратегія прогнозу полягає у тому, що розробляються різні варіанти сценарію розвитку на певну перспективу, визначаються критерії ïx оцінки i після розрахунків на прогностичній 
моделі 3 них вибираються оптимальні як такі, що найкращим чином відповідають заданій системі цілей. Відповідно до загальної стратегії рішення прогнозних задач виконується у певній послідовності, що за алгоритмом соціоактогенезу визначає таку стадійність:

1. Усвідомлення i формулювання суспільної потреби стосовно геодемографічних процесів в даній соціогеосистемі, тобто, визначення основної проблеми, наприклад, встановлення факту потреби у якісних та кількісних змінах системи відтворення населення. Далі формулюється мета і визначаються заходи та ресурси для ï забезпечення.

2. Будується система цілей для досягнення поставленої мети. Система цілей розбиває рішення загальної задачі (мету) на окремі стадій, етапи і конкретні завдання, виконання яких у сукупності повинно привести до досягнення очікуваного результату. Тому вектори цілей повинні бути узгодженими, а кожна ціль забезпечена ресурсами. Для часової координації вирішення поставлених завдань складається графік досягнення кожної цілі 3 урахуванням конкретних умов.

3. Формується виконавча система, першим етапом чого $\epsilon$ прогнозне моделювання. За його результатами визначаються умови, методи та засоби досягнення поставленої мети, тобто, елементи майбутньої системи суспільних дій. 3 цього випливає, що прогнозне моделювання $є$ одним 3 найважливіших i найвідповідальніших етапів формування виконавської системи.

4. Отримання результату дії виконавської системи. Якщо він відповідає очікуванню, створена виконавська система визнається задовільним інструментом управління геодемографічним процесом i функціонує далі. У протилежному випадку необхідно повернутися до третього етапу і повторити всі дії.

При підготовці вихідних даних для прогнозування необхідно враховувати наступне. Варіабельність стану зовнішнього середовища (зовнішніх факторів) доповнюється бажаними або очікуваними змінами внутрішнього функціонування геодемографічної системи, внаслідок чого виникає досить багато сценаріїв розвитку геодемографічної системи в широкому діапазоні зовнішніх i внутрішніх факторів. Додатково до цього обгрунтовується і встановлюється множина (система) критеріїв оцінки прогнозованого стану системи відповідно до цілей її розвитку. Як прийнято в оціночно-прогностичному моделюванні, множина можливих варіантів розвитку системи обов'язково включає найкращий (оптимістичний), найгірший (песимістичний) і деякий середній (реалістичний) сценарій. Всі інші сценарії $\epsilon$ комбінаціями вказаних трьох основних варіантів.

Можливі сценарії для прогнозуванні розвитку геодемографічної системи формалізуються i параметризуються у вигляді конкретних граничних умов (наприклад, змін коефіцієнтів народжуваності, смертності та міграції за віковими групами, покращання або погіршення соціальних умов функціонування, вживання спеціальних заходів стимулювання народжуваності, зменшення смертності, зміни інтенсивності та напрямку міграції тощо). Важливо, щоб граничні умови для прогнозу були максимально реалістичними та обгрунтованими для мінімізації похибки прогнозу. Вони визначаються методами екстраполяції трендових залежностей, встановлених та розрахованих на стадії епігнозного моделювання, i належним чином схематизуються - обчислюються середні, модальні або медіанні значення окремих змінних, параметри лінійних або нелінійних рівнянь регресії тощо.

Після розрахунку всіх заданих варіантів прогнозу здійснюється оцінка результатів за допомогою багатовимірної системи критеріїв. Розглядаючи кожний варіант як альтернативну можливість досягнення мети, можна використати методи багатовимірної класифікації, моделювання траєкторії розвитку, описані вище, або методи багатокритеріальної оптимізації. Незалежно від методів відбору оптимального варіанту він повинен безумовно забезпечити досягнення головної мети.

\section{Використання оціночно-прогностично} моделі у процесі управління формуванням i розвитком регіональної геодемографічної ситуації передбачає іiі інтеграцію в систему геодемографічного моніторингу як інструменту оптимізації і підвищення ефективності суспільного управління. Взагалі система моніторингу у будь-якій системі управління має головним завданням збір і обробку інформації, яка поступає каналами зворотного зв'язку і відображає реакцію керованого об'єкту на управлінські дії.

Моніторингова інформація за кожним циклом (фазою) управління обробляється 3 метою виявлення відхилень від запланованого розвитку об’єкту, пошуку їх причин і підготовки рекомендації 3 корекції управлінських рішень на наступному циклі управління. Для цього ідеальним методом $є$ моделювання траєкторії розвитку геодемографічної системи у багатовимірному ознаковому просторі, описаний вище. За його допомогою за моніторинговими параметрами просто та надійно ідентифікуються відхилення від оптимальної траєкторії розвитку і знаходяться їх кількісні оцінки. На основі опису зв'язків між змінними управління i моніторинговими параметрами будуються управлінські гіпотези для коригування траєкторії розвитку ГДС на наступному циклі управління. Найбільшу складність у процесі підготовки та прийняття управлінських рішень представляє саме тестування гіпотез управління, яких, як правило, декілька - основна та альтернативні. Розглянемо сутність такої перевірки.

В технологічних процесах виробництва, які $\epsilon$ жорстко детермінованими і не допускають ніяких випадкових відхилень, зв'язки між компонентами вхідного і вихідного векторів управління процесом мають функціональний характер i описуються диференційними чи алгебраїчними рівняннями, рішення яких має бути строго однозначним. В таких системах управління нема місця випадковим процесам, тому всі процедури прийняття рішень 
формалізовані, а параметри для коригування управління технологічним процесом визначаються 3 великою точністю. Але в управлінні соціальними i природними системами, де ймовірність $€$ визначальною характеристикою, а процеси принципово випадкові, автоматичні алгоритми підготовки управлінських рішень $є$ неефективними. Участь людини у підготовці і прийнятті управлінських рішень $є$ неодмінною і вирішальною. У зв'язку 3 ймовірнісним характером геодемографічних процесів тестування управлінських гіпотез є особливо складним завданням, головним чином тому, що вимагає одночасного врахування багатьох факторів і умов, у яких функціонує геодемографічна система. Єдиним засобом інтеграції всієї доступної інформації стосовно розвитку геодемографічної системи $€$ ïi математична оціночно-прогностична модель.

Слід підкреслити, що управління геодемографічною системою на макрорівні $€$ неперервним процесом, у якому умовно виокремлюються цикли (фази) управління, що зумовлено особливостями отримання та обробки моніторингової інформації, підготовки, прийняття та реалізації управлінських рішень. Якщо отримання та обробку моніторингових параметрів можна організувати 3 досить великою частотою, щоб вважати ці процеси неперервними, то оперування управлінськими рішеннями $є$ процесом дискретним. Отже, цикл (фаза) управління визначається проміжком часу між реалізацією послідовних управлінських рішень на основі аналізу накопичених моніторингових даних. Як показано в попередніх роботах [4], кожна фаза управління $\epsilon$ інваріантною послідовністю певних дій, пов'язаних з отриманням, обробкою моніторингової інформації, підготовкою, прийняттям та реалізацією управлінських рішень. Формулювання і тестування управлінських гіпотез на стадії підготовки управлінських рішень $є$ ключовою ланкою фази управління, бо саме на цьому етапі формується тактичний план управління для наступної фази. Отже, ефективність та успішність управління визначаються коректністю, якістю та детальністю тестування управлінських гіпотез. Застосування у цій ситуації адаптованої оціночно-прогностичної моделі технологічно зводиться до рішення прогнозної задачі на коротку перспективу (одна фаза управління), але із значно більшим обсягом інформаційного забезпечення. В ідеальному випадку доцільно залучити для тестування гіпотез управління результати компонентного аналізу, які за кожним параметром відображають «вузькі місця» і локальні проблеми процесу управління.

Можливість створення цифрового образу майбутнього стану геодемографічної системи наприкінці наступної фази управління (образу їх очікуваного, тактично ідеального стану) надає процесу моніторингу конкретного характеру. Принципово можна в on-line режимі ідентифікувати початок відхилень розвитку від запланованої траєкторії i заздалегідь вдатися до коригуючих дій, не чекаючи досягнення критичного значення відхилень чи закінчення поточної фази управління. Це перетворює процес суспільного управління в прозорий i зрозумілий процес переходу геодемографічної системи в новий передбачуваний, неперервно керований і очікуваний стан.

Оцінка та обговорення результатів, висновки. Створення постійнодіючої моделі регіональної геодемографічної системи $є$ перспективною граничною реалізацією ідеї застосування запропонованої оціночно-прогностичної моделі в суспільному управлінні. Першим кроком до цього може бути структурно-функціональна інтеграція системи геодемографічного моніторингу в модель регіональної геодемографічної системи 3 організацією відповідних процедур і засобів обміну, аналізу і накопичення інформації. 3 одного боку, це дозволить уникнути процедур перетворення i передачі моніторингової інформації через проміжні структури та унеможливить іiі втрати та спотворення. 3 іншого боку, подібний інформаційноаналітичний блок системи суспільного управління дасть можливість максимально забезпечити вимоги керованості та спостережності геодемографічної системи при підготовці управлінських рішень до прийняття в on-line режимі. Фактично така організація суспільного управління перетворить його на неперервний процес 3 можливістю довільного контролю за кожним моніторинговим параметром i практично миттєвою реакцією на можливі загрози і виклики. У такій системі управління людина, використовуючи свій творчий потенціал, буде інтуїтивно знаходити найкоротші шлях вирішення виникаючих проблем, а тактичні і технічні питання будуть вирішуватись на постійно діючій моделі.

У більш віддаленій перспективі мова може йти про створення тотальної постійно діючої моделі суспільно-географічного процесу в регіональній соціогеосистемі, у якій модель регіональної геодемографічної системи буде важливою складовою, функціонально і структурно поєднаною 3 аналогічними моделями інших функціональних підсистем соціогеосистеми. Перевагою такої загальної моделі буде можливість врахування величезної кількості параметрів суспільногеографічного процесу для вирішення будь-яких проблем суспільного розвитку.

\section{References:}

1. Kustovs'ka O. V. Demografičnij rozvitok regionu (statističnij analiz i modelûvannâ) [Demographic development of the region (statistical analysis and modeling)] Ternopil: Ekonomichna dumka, 2008, 326 p. (In Ukrainian).

2. Libanova E. M. Lûds'kij rozvitok regìnìv Ukraïni: metodika ocìnki ta sučasnij stan [Human Development of the Regions of Ukraine: Methods of Assessment and Current Status], Kyiv, 2002, 111 p. (In Ukrainian). 
3. Nêmec' K. A., Sehida K. Yu., Nyemets' L. M. Bagatovimìrnij analiz v suspil'nìj geografï (netradicìnì metodi) [Multidimensional analisis in human geography: non-traditional methods], Kharkiv, 2016, 120 p. (In Ukrainian).

4. Nêmec' L., Segìda K., Guseva N. Demographic potential as the basis for social and economic development. Economic Annals-XXI, 2015, N. 3-4, pp. 93-97.

5. Nêmec' L. M., Segìda K. Yu., Nêmec' K. A. Demografičnij rozvitok Harkìvs'kogo regìonu [Demographic development of the Kharkiv region], Kharkiv, 2012, 200 p. (In Ukrainian).

6. Ptoukha Institute for Demography and Social Studies of the National Academy of Sciences of Ukraine. Available at: http://database.ukrcensus.gov.ua

7. Segìda K. Definiciâ ponâtiâ «geodemografičeskaâ sistema» s pozicii obŝestvennoj geografii. Mogilevskij meridian [Mogilev Meridian], 2017, N. 1-2 (37-38), p. 51-56. (In Russian).

8. Stecenko S. H. Demografična statistika [Demographic statistics], Kyiv: Vyshcha shkola, 2005, 415 p. (In Ukrainian).

9.Kharkiv RegionDevelopmentStrategy for2020.Accessmode:http://kharkivoda.gov.ua/documents/16203/1088. pdf (In Ukrainian)

10. Âvors'ka V.V. Regìnal'nì demografičnì procesi v Ukraïnì [Regional demographic processes in Ukraine], Kamianets-Podils'kyi: Aksioma, 2013, 384 p. (In Ukrainian).

11. Êsìnova N. İ., Bezugla T. V. Demografičnij rozvitok naselennâ Ukraïni [Demographic development of the Ukrainian population]. Ekonomična strategiâ ì perspektivi rozvitku sferi torgìlì ta poslug [Economic strategy and prospects for the development of trade and services], 2008, pp. 368-375 (In Ukrainian). 